\title{
Genomic and Toxigenic Heterogeneity of Bacillus cereus sensu lato Isolated from Ready-to-Eat Foods and Powdered Milk in Day Care Centers in Colombia
}

\author{
Jennifer Sánchez Chica, ${ }_{1}$ Margarita M. Correa, ${ }^{1}$ Angel E. Aceves-Diez, ${ }^{2}$ Geertrui Rasschaert, ${ }^{3}$ \\ Marc Heyndrickx, ${ }^{3,4}$ and Laura M. Castañeda-Sandoval ${ }^{5}$
}

\begin{abstract}
Bacillus cereus sensu lato (s.l.) is a group of bacteria commonly found in diverse environments, including foods, with potential to cause emesis and diarrhea. In Colombia, it is one of the main foodborne pathogens. The aim of this study was to determine the genomic and toxigenic heterogeneity of B. cereus s.l. isolated from ready-to-eat foods and powdered milk collected in day care centers of Medellin, Colombia. Of 112 B. cereus s.l. isolates obtained, $94 \%$ were $\beta$-hemolytic. Toxigenic heterogeneity was established by the presence of $n h e A B C$, $h b l C D A B, c y t K 2$, entFM, and $c e s B$ toxigenic genes. The nheABC operon and entFM gene were most frequently detected in the isolates, whereas the ces $B$ gene was not found. According to the toxin genes content, nine toxigenic profiles were identified. A $44 \%$ of isolates had profiles with all genes for nonhemolytic enterotoxin, hemolysin BL, and enterotoxin FM production (profiles II and IV). Pulsed-field gel electrophoresis analysis indicated a high genomic heterogeneity among the B. cereus s.l., with 68 isolates grouping into 16 clusters and 33 placed separately in the dendrogram. This study provides useful information on the safety of ready-to-eat foods and powdered milk in day care centers where children, a susceptible population, are exposed and it should incentive for more studies to understand the distribution of different toxin-encoding genes among B. cereus s.l. isolates, enabling detailed risk assessment.
\end{abstract}

Keywords: Bacillus cereus, enterotoxin, emetic toxin, genomic diversity, toxigenic profile

\section{Introduction}

T HE BACILLUS CEREUS group or B. cereus sensu lato (s.l.) includes spore-forming, facultative anaerobic, Grampositive and motile rod bacteria commonly found in diverse environments (Ceuppens et al., 2013). Nine members of the group are recognized, Bacillus anthracis, Bacillus cytotoxicus, Bacillus mycoides, Bacillus pseudomycoides, B. cereus sensu stricto (s.s.), Bacillus thuringiensis, Bacillus toyonensis, Bacillus weihenstephanensis (Jiménez et al., 2013), and Bacillus wiedmannii (Miller et al., 2016). In addition, new species have recently been proposed based on molecular analysis (Liu et al., 2017). The heat-resistant pathogen B. cereus s.l. is naturally found in soil, which constitutes a risk factor for food contamination and foodborne infection or intoxication, because the spores survive cooking or pasteurization processes (De Jonghe et al., 2008).
Among the foods susceptible to be contaminated are ready-to-eat foods, sausages, and dairy products (raw, pasteurized and dried whole milk, and yoghurt) (Banykó and Vyletelová, 2009; Kumari and Sarkar, 2014; Yang et al., 2017; Alvarenga et al., 2018). In Colombian households and schools, B. cereus s.l. has been detected in cheeses, raw vegetables, ready-to-eat cereals, and flours (Forero et al., 2018), also in rice and not industrially prepared ready-to-eat foods (INS, 2011). In 2016, it was referred as one of the main foodborne pathogens in the country (Forero et al., 2018).

B. cereus s.l. produces food poisoning with diarrhea and/or emesis and causes outbreaks that are often underestimated (Papan et al., 2019). The emetic syndrome is generated by the emetic toxin, cereulide (Logan, 2012), encoded by the ces gene cluster (cesHPTABCD), located on a plasmid in strains belonging to a particular lineage of B. cereus s.s. (Økstad and Kolst $\varnothing, 2011)$. The diarrheal syndrome is associated to three

\footnotetext{
${ }^{1}$ Grupo de Microbiología Molecular and ${ }^{5}$ Grupo BioMicro, Escuela de Microbiología, Universidad de Antioquia, Medellín, Colombia.

${ }^{2}$ Laboratorios Minkab, Departamento de Investigación y Desarrollo, Guadalajara, Jalisco, Mexico.

${ }^{3}$ Flanders Research Institute for Agriculture, Fisheries and Food (ILVO), Technology and Food Science Unit, Melle, Belgium.

${ }^{4}$ Department of Pathology, Bacteriology and Avian Diseases, Ghent University, Merelbeke, Belgium.
} 
different enterotoxins coded in the bacterial chromosome. The hemolysin BL (HBL) is encoded by the $h b l$ operon ( $h b l C D A$ or $h b l C D A B$ that includes the $h b l B$ pseudogene), and the nonhemolytic enterotoxin (NHE) is encoded by the nhe operon (nheABC) (Logan, 2012). The cytotoxin $\mathrm{K}$ includes two variants, CytK1, encoded by the $c y t K 1$ gene, has a high cytotoxic activity, and CytK2, encoded by cytK2, is the most common variant (Stenfors et al., 2008). In addition, most B. cereus strains are potential producers of enterotoxin FM (EntFM), codified by the entFM gene (Ceuppens et al., 2013).

Knowledge about genomic heterogeneity, including intraspecific diversity and toxigenic profiles of B. cereus, is important to differentiate potential clinical isolates, to find contamination sources, track isolates along the food chain, and elucidate strain distribution within foods (De Jonghe et al., 2008). In Colombia there are reports of the detection of $B$. cereus enterotoxin genes $(\mathrm{hblC}$, nheA, and cytK2) directly in powdered foods such as dietary complement for children and cassava starch (Sánchez et al., 2014), and of B. cereus strains producing $\mathrm{HBL}$ in rice and ready-to-eat cereals (Forero et al., 2018).

Considering that (1) the number of day care centers is rapidly growing around the world (Guirdham, 2019), (2) children deserve adequate care and special attention regarding food preparation and their safety, and (3) in Colombia $B$. cereus is an important cause of foodborne disease in scholar children (INS, 2007; Forero et al., 2018), this study aimed to determine the genomic and toxigenic heterogeneity of $B$. cereus s.l. isolates in ready-to-eat foods and powdered milk collected in day care centers of Medellin, Colombia. This information will contribute to food safety/risk assessment in institutions such as day care centers where children, a susceptible population, consume these foods.

\section{Materials and Methods}

\section{Food sampling}

A total of 327 food samples were randomly collected at day care centers (A-L) in Medellín, Colombia. Collections were performed four times spanning a month, 252 ready-toeat foods were collected from September 2016 to November 2017 and included the following: fruit juice $(n=34)$, meat $(n=33)$, soup $(n=32)$, salad $(n=30)$, cooked rice $(n=29)$, milk beverage $(n=29)$, potato puree $(n=17)$, fried egg $(n=13)$, cheese $(n=12)$, corn-arepa $(n=8)$, fried ripe banana $(n=7)$, pasta $(n=5)$, bread $(n=2)$ and cooked cassava $(n=1)$. In addition, 75 powdered milk samples collected from May to August 2013 were included in the analysis.

\section{Bacterial strains and processing}

B. cereus s.l. were isolated and identified from ready-to-eat foods and powdered milk samples according to the ISO 7932:2004 method (ISO, 2004). B. cereus s.s. F4810/72 (emetic), ATCC 14579 (enterotoxigenic) and ATCC 21281 (enterotoxigenic), and B. thuringiensis 4D22 and 4AH1, were used as reference strains to standardize molecular procedures. Reference strains and food isolates were kept in cryo-tubes containing Luria-Bertani (LB) broth (Sigma, St Louis, MO) with $30 \%$ (v/v) glycerol (Merck, Darmstadt, Germany) and stored at $-80^{\circ} \mathrm{C}$. Lecithinase activity was determined on mannitol egg yolk polymyxin agar, MYP (Merck). Hemolytic activity was analyzed on blood agar with $5 \%$ sheep blood (Becton Dickinson, Heidelberg, Germany) (ISO, 2004).

\section{Identification of B. cereus s.I. toxin genes by multiplex polymerase chain reaction}

To identify B. cereus s.l. toxin genes, total DNA was extracted from $18 \mathrm{~h}$ grown LB broth cultures as previously described (D'Alessandro et al., 2007). DNA was quantified with a Nanodrop 2000 (Thermo Fisher Scientific, MA). To detect $B$. cereus s.l. toxin genes three multiplex polymerase chain reaction (mPCR) assays (1-3) were applied. The final reaction mixture for mPCRs consisted of $600 \mu \mathrm{M}$ dNTPs mix, $4 \mathrm{mM}$ $\mathrm{MgCl}_{2}, 1.3 \mathrm{U}$ of Taq DNA polymerase (Thermo Fisher Scientific), $1.6 \mu \mathrm{L} 10 \times$ reaction buffer, $100 \mathrm{ng}$ of $B$. cereus s.l. DNA template, and $0.2 \mu \mathrm{M}$ primer pairs added according to the genes amplified in each mPCR (Supplementary Table S1); for the internal transcribed spacer (ITS1), used as the internal amplification control in the first $\mathrm{mPCR}, 0.1 \mu \mathrm{M}$ primers were added.

A mix of DNAs from $B$. cereus $\mathrm{F} 4810 / 72$ and $B$. cereus ATCC 14579 reference strains was used as positive control of toxin genes. A reaction mixture without DNA template was used as the PCR-negative control. Amplification in mPCRs was performed using a DNA thermocycler MyCycler (Bio$\mathrm{Rad}, \mathrm{CA})$ with an initial denaturation at $94^{\circ} \mathrm{C}$ for $5 \mathrm{~min}$, followed by 35 cycles of each, $20 \mathrm{~s}$ denaturation at $94^{\circ} \mathrm{C}, 40 \mathrm{~s}$ annealing at $50^{\circ} \mathrm{C}$ and 2 min elongation at $72^{\circ} \mathrm{C}$, and a final incubation at $72^{\circ} \mathrm{C}$ for $5 \mathrm{~min}$.

\section{Genomic diversity of $\mathrm{B}$. cereus s.I. isolates by pulsed-field gel electrophoresis}

The pulsed-field gel electrophoresis (PFGE) method for characterization of $B$. cereus s.l. isolates used DNA plugs obtained as previously described (Gholamiandekhordi et al., 2006). The bacterial cultures had an optical density of 1.5 at $610 \mathrm{~nm}$. DNA plugs were restricted using $20 \mathrm{U}$ Not I endonuclease (Thermo Fisher Scientific) at $37^{\circ} \mathrm{C}$ for $4 \mathrm{~h}$. DNA fragments were separated on a $1 \%$ SeaKem Gold agarose (Lonza, Basel, Switzerland) gel using a CHEF-Mapper (Bio$\mathrm{Rad})$, with the following optimized parameters: low molecular weight $=20 \mathrm{~Kb}$ and high molecular weight $=700 \mathrm{~Kb}$, running time $=21 \mathrm{~h}$, initial switch time $=5 \mathrm{~s}$, final switch time $=80 \mathrm{~s}$ and tank temperature $=14^{\circ} \mathrm{C}$. PFGE profiles were observed using a G:Box with a GeneSnap 7.12 (Syngene, Cambridge, United Kingdom) after staining the gels for $30 \mathrm{~min}$ in $400 \mathrm{~mL}$ of a $1 \mu \mathrm{g} / \mathrm{mL}$ ethidium bromide solution (Carl Roth, Karlsruhe, Germany) and destaining for $30 \mathrm{~min}$ in a $500 \mathrm{~mL}$ distilled water bath.

\section{Data analysis}

Cluster analysis was performed using BioNumerics v 7.6 software (Applied Maths, Sint-Martens-Latem, Belgium). The PFGE banding patterns were normalized by alignment with the Salmonella ser. Braenderup H9812 chromosome restricted with $\mathrm{XbaI}$ endonuclease, used as size standard marker (Dréan et al., 2015). A similarity analysis was conducted using the Dice coefficient and the unweighted pair group method with arithmetic mean, optimization, and tolerance settings at $1 \%$. A similarity value of $84 \%$ was used to group the isolates in clusters (Gdoura-Ben Amor et al., 2018), based on visual determination. 


\section{Results and Discussion}

\section{B. cereus s.I. isolates recovered from foods}

A total of 112 B. cereus s.l. were isolated from foods. There are no reports that these isolates were involved in food poisoning cases. The $B$. cereus s.l. were isolated from cheese $(n=22)$, cooked rice $(n=14)$, fried eggs $(n=4)$, fruit juice $(n=27)$, milk beverage $(n=13)$, potato puree $(n=2)$, powdered milk $(n=6)$, salad $(n=11)$, and soup $(n=13)$. The $\beta$-hemolytic activity was detected in $105 \mathrm{~B}$. cereus s.l. isolates $(94 \%)$, observed as a transparent halo around the colony. Similar to this result, other studies have reported high frequencies $(>80 \%)$ of hemolytic activity in B. cereus isolates from ice cream (Arslan et al., 2014) and milk, ready-to-eat dishes and spices (Chaves et al., 2011). Of interest, of 47 isolates that were negative for the $h b l$ genes, 45 presented $\beta$-hemolysis, which suggests that they probably produce other proteins with hemolytic activity such as cereolysin $\mathrm{O}$, hemolysines II, or/and III (Ramarao and Sanchis, 2013).

All B. cereus s.l. isolates were able to degrade lecithin. This characteristic constitutes the first step to identify presumptive B. cereus according to international standards (ISO, 2004). However, some B. cereus isolates may lack the capacity to produce lecithinase (Chaves et al., 2011); therefore, these strains would not be identified in standard media as MYP (Fricker et al., 2008). The fact that hemolytic and lecithinase activities can vary among $B$. cereus strains suggests that although phenotypic analysis is a very important initial step for strain identification, it should be complemented with genomic characterization.

\section{Table 1. Toxigenic Profiles of Bacillus cereus sensu lato Isolated from Foods in Day Care Centers}

\begin{tabular}{|c|c|c|c|c|}
\hline Toxigenic profile & Toxin genes & $\begin{array}{c}\text { Number } \\
\text { of isolates } \\
\text { (frequency \%) }\end{array}$ & $\begin{array}{l}\text { Day care } \\
\text { centers }\end{array}$ & $\begin{array}{l}\text { Foods (number of } \\
\text { isolates), total }=112\end{array}$ \\
\hline \multirow[t]{5}{*}{ I } & \multirow[t]{5}{*}{ nhe $A B C$, hblCDAB, cytK2, entFM } & \multirow[t]{5}{*}{$12(10.7)$} & $\mathrm{C}$ & CR (1), LS (3), PP (2) \\
\hline & & & $\mathrm{F}$ & $\mathrm{MB}(1)$ \\
\hline & & & G & MB (1) \\
\hline & & & $\mathrm{H}$ & $\mathrm{CH}(2)$ \\
\hline & & & $\mathbf{J}$ & SA (2) \\
\hline \multirow[t]{9}{*}{ II } & \multirow[t]{9}{*}{ nhe $A B C$, hblCDAB, entFM } & \multirow[t]{9}{*}{$20(17.9)$} & $\mathrm{B}$ & OS (1) \\
\hline & & & $\mathrm{C}$ & CR (6), LS (3) \\
\hline & & & $\mathrm{D}$ & $\mathrm{MB}(2)$ \\
\hline & & & $\mathrm{E}$ & $\mathrm{FE}(1)$ \\
\hline & & & $\mathrm{G}$ & SA (1) \\
\hline & & & $\mathrm{H}$ & $\mathrm{CH}(2), \mathrm{SA}(1)$ \\
\hline & & & I & $\mathrm{FJ}(1)$ \\
\hline & & & $\mathrm{J}$ & SA (1) \\
\hline & & & $\mathrm{L}$ & PM (1) \\
\hline \multirow[t]{2}{*}{ III } & \multirow[t]{2}{*}{ nhe $A B C$, hblCDA, cytK2, entFM } & \multirow[t]{2}{*}{$2(1.8)$} & $\mathrm{H}$ & $\mathrm{CH}(1)$ \\
\hline & & & $\mathrm{K}$ & PM (1) \\
\hline \multirow[t]{7}{*}{ IV } & \multirow[t]{7}{*}{ nhe $A B C$, hblCDA, entFM } & \multirow[t]{7}{*}{$29(25.9)$} & B & $\mathrm{CH}(4), \mathrm{FJ}(4), \mathrm{MB}(1)$ \\
\hline & & & $\mathrm{C}$ & $\mathrm{CH}(1), \mathrm{CR}(6)$ \\
\hline & & & $\mathrm{D}$ & SS (1) \\
\hline & & & $\mathrm{E}$ & FE (3) \\
\hline & & & $\mathrm{G}$ & SA (1) \\
\hline & & & $\mathrm{H}$ & $\mathrm{CH}(7)$ \\
\hline & & & $\mathrm{I}$ & SA (1) \\
\hline \multirow[t]{2}{*}{$\mathrm{V}$} & \multirow[t]{2}{*}{ nhe $A B C$, hblCDA } & \multirow[t]{2}{*}{$2(1.8)$} & $\mathrm{C}$ & CR (1) \\
\hline & & & $\mathrm{H}$ & $\mathrm{CH}(1)$ \\
\hline VI & nheABC, hblA, cytK2, entFM & $1(0.9)$ & $\mathrm{B}$ & $\mathrm{CH}(1)$ \\
\hline \multirow[t]{7}{*}{ VII } & \multirow[t]{7}{*}{$n h e A B C$, cytK 2, entFM } & \multirow[t]{7}{*}{$12(10.7)$} & A & $\mathrm{FJ}(1), \mathrm{MB}(1)$ \\
\hline & & & B & $\mathrm{CH}(2)$ \\
\hline & & & $\mathrm{E}$ & MB (1) \\
\hline & & & $\mathrm{F}$ & $\mathrm{FJ}(2)$ \\
\hline & & & I & FJ (1) \\
\hline & & & $\mathrm{J}$ & SA (3) \\
\hline & & & $\mathrm{K}$ & SA (1) \\
\hline \multirow[t]{4}{*}{ VIII } & \multirow[t]{4}{*}{$n h e A B C$, entFM } & \multirow[t]{4}{*}{$28(25)$} & $\mathrm{B}$ & $\mathrm{CH}(1)$ \\
\hline & & & $\mathrm{D}$ & FJ (15), MB (5), SS (4), VS (1) \\
\hline & & & $\mathrm{K}$ & PM (1) \\
\hline & & & $\mathrm{L}$ & PM (1) \\
\hline \multirow[t]{3}{*}{ IX } & \multirow[t]{3}{*}{ nheABC } & \multirow[t]{3}{*}{$6(5.3)$} & $\mathrm{D}$ & FJ (3), MB (1) \\
\hline & & & $\mathrm{K}$ & PM (1) \\
\hline & & & $\mathrm{L}$ & PM (1) \\
\hline
\end{tabular}

$\mathrm{CH}$, cheese; CR, cooked rice; FE, fried eggs; FJ, fruit juice; LS, lentil soup; MB, milk beverage; OS, oat soup; PM, powdered milk; PP, potato puree; SA, salad; SS, spinach soup; VS, vegetables soup. 
A 10

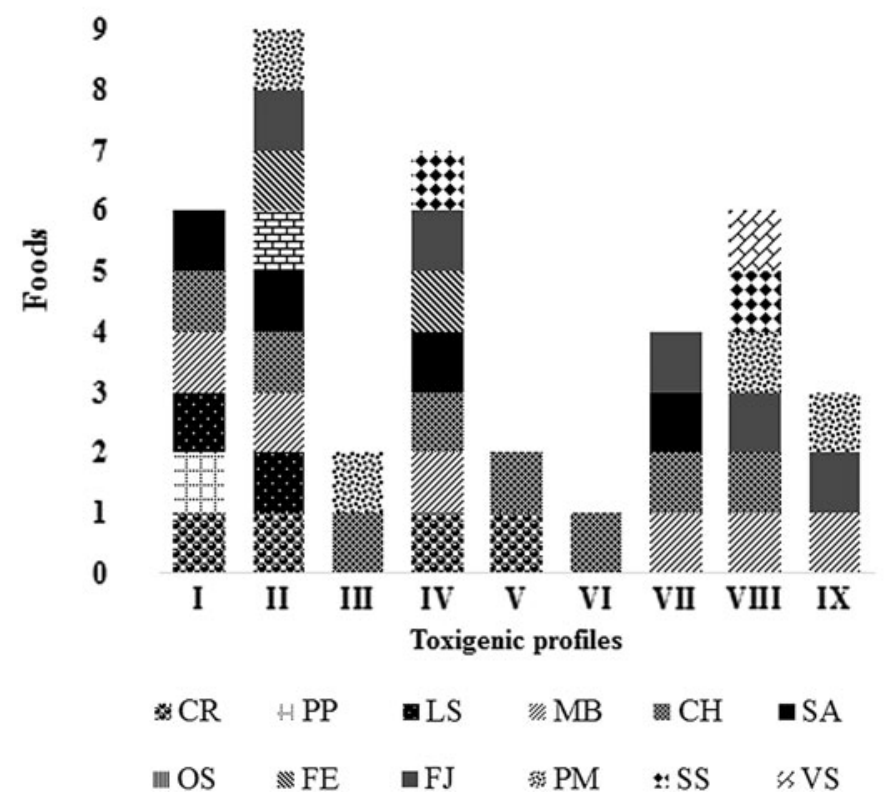

B 10

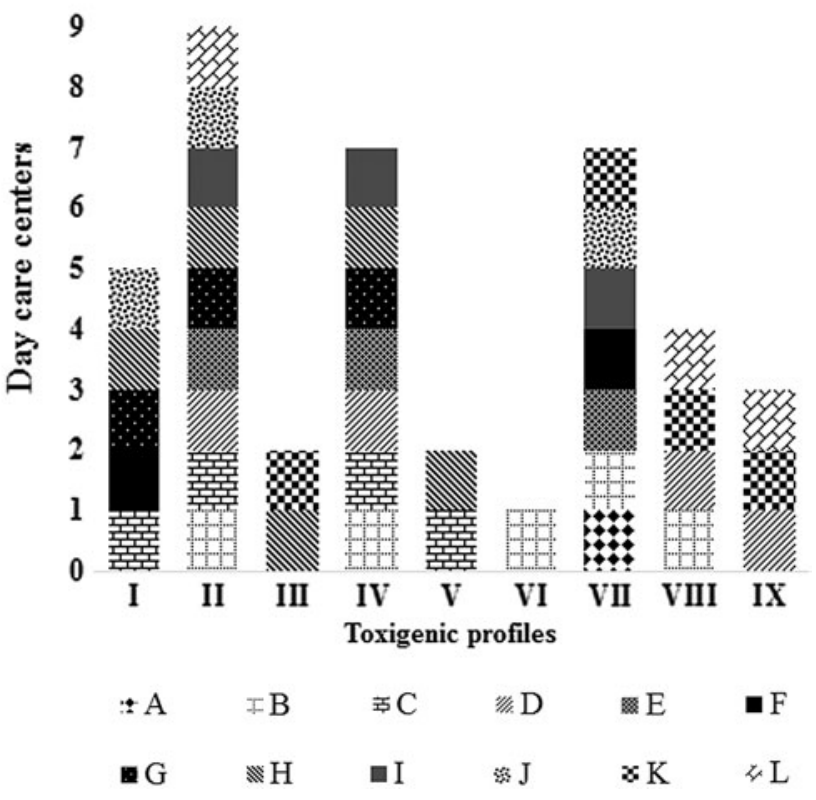

FIG. 1. Distribution of Bacillus cereus sensu lato toxigenic profiles according to food types and day care centers. (A) Distribution of toxigenic profiles in foods. (B) Distribution of toxigenic profiles in day care centers $(\mathrm{A}-\mathrm{L})$. $\mathrm{CH}$, cheese; CR, cooked rice; FE, fried eggs; FJ, fruit juice; LS, lentil soup; MB, milk beverage; OS, oat soup; PM, powdered milk; PP, potato puree; SA, salad; SS, spinach soup; VS, vegetables soup.

\section{Toxigenic heterogeneity of $\mathrm{B}$. cereus s.I. isolates}

Toxigenic characterization of the isolates by $\mathrm{mPCR}$ showed that the nhe operon was present in all isolates, entFM gene in $92.9 \%$ of isolates, $c y t K 2$ gene in $24.1 \%, h b l C D A B$ in $28.6 \%, h b l C D A$ in $29.5 \%$, and $h b l A$ in one isolate $(0.9 \%)$; isolates carrying ces $B$ gene were not identified. Similar to these results, a large distribution of toxin genes is observed in other countries all over the world such as Korea, Latvia, and Canada, with the enterotoxin genes (particularly, nhe operon and entFM) present in higher frequencies, and the emetic toxin genes were not detected (Lee et al., 2017; Saleh-Lakha et al., 2017; Fogele et al., 2018).

The nhe operon being present in all B. cereus s.l. isolates is in agreement with the suggestion that its high frequency is owed to its vertical inheritance, promoted by an unknown but relevant fitness function; conversely, the $h b l$ operon and the cyt $K$ are commonly mobilized and horizontally transmitted (Böhm et al., 2015). In addition, the cytK2 gene detected in this study is the most common variant of the cyt $K$ gene present in B. cereus group members (Stenfors et al., 2008); the $c y t K 1$ gene is exclusive of $B$. cytotoxicus initially reported in France (Lund et al., 2000).

None of the isolates carried cesB gene, therefore, they were not able to produce the emetic toxin. This is a frequent finding (Altayar and Sutherland, 2006) with few exceptions of studies that have found $B$. cereus emetic strains in various foods (López et al., 2015; Park et al., 2016; Lee et al., 2017; Lin et al., 2017; Mudagza and Buys, 2017; Yang et al., 2017; Frentzel et al., 2018). In Colombia, the cesB gene was detected in DNA directly extracted from cassava starch (Sánchez et al., 2014); however, there are no reports about isolated emetic strains. Probably the reason for this low frequency is because the emetic strains belong to particular lineage of B. cereus s.s. (Økstad and Kolstø, 2011) that may have a low circulation in Colombia; in addition, the cereulide synthetase gene (ces) cluster is harbored on a megaplasmid horizontally transferred, called pBCE (Logan, 2012).

In total, nine toxigenic profiles were identified according to toxin genes presence (Table 1). Most of the isolates (43.8\%) had profiles with all genes for NHE, HBL, and EntFM production (profiles II and IV), whereas $12.5 \%$ of the isolates had profiles with all genes for HBL, NHE, CytK, and EntFM (profiles I and III). The toxigenic profile VIII (25\%) included isolates carrying genes for NHE and EntFM. Of interest, one isolate harbored an incomplete $h b l$ operon (only $h b l A$, profile $\mathrm{VI}$ ), suggesting the presence of a toxin gene polymorphism and therefore, the production of a nonfunctional HBL because the three components, hblCDA, are necessary to generate an active toxin (Stenfors et al., 2008).

The toxigenic profiles obtained are in agreement with those reported for $B$. cereus isolated from foods worldwide (Ankolekar et al., 2009; López and Alippi, 2010; Chaves et al., 2011; Samapundo et al., 2011; Arslan et al., 2014; Kim et al., 2014; Saleh-Lakha et al., 2017; Fogele et al., 2018), with B. cereus carrying predominantly genes encoding diarrheal toxins. Although many of these studies reported that the most common B. cereus toxigenic profile harbored all the genes for the NHE, HBL, and EntFM plus the cytotoxin $\mathrm{K}$ gene (Chaves et al., 2011; Samapundo et al., 2011; Fogele et al., 2018), in this study the predominant toxigenic profiles did not include $c y t K 2$ (profiles IV and VIII). The cytK2 gene was found in $24.1 \%$ of profiles; this result is in agreement with previous reports in which the $c y t K$ gene is found in low frequency (Lin et al., 2017; Mudagza and Buys, 2017), or is not even detected (Arslan et al., 2014; Silva et al., 2014; Frentzel et al., 2018).

When observing the distribution of $B$. cereus toxigenic profiles in relation to food type (Fig. 1A), or day care center 


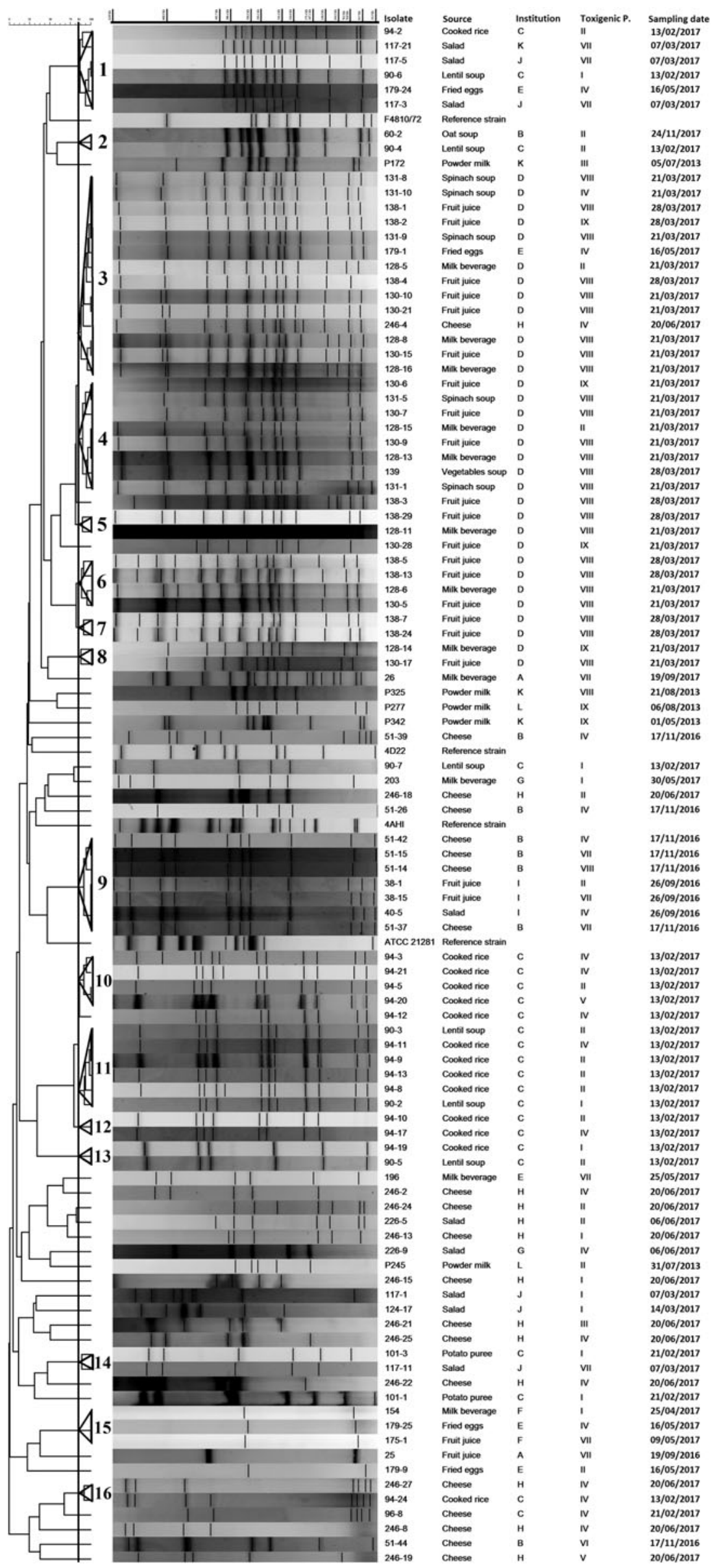

FIG. 2. Pulsed-field gel electrophoresis dendrogram showing the relationship among Bacillus cereus sensu lato isolated from foods. The delineation level for clusters (indicated by bold vertical line) is visually set at $84 \%$ and clusters are shown in triangles. 
Table 2. Genomic Diversity and Toxigenic Profiles in Bacillus CEREus sensu lato Isolates from Different Day Care Centers and Food Samples

\begin{tabular}{llcl}
\hline PFGE cluster & Toxigenic profiles (isolates number) & Institution & Food samples (isolates number) \\
\hline 1 & I (1), II (1), IV (1), VII (3) & C & CR (1), LS (1) \\
& & E & FE (1) \\
& & J & SA (2) \\
2 & II (2) & K & SA (1) \\
3 & II (1), IV (3), VIII (9), IX (1) & B & OS (1) \\
& & C & LS (1) \\
4 & FJ (6), MB (3), SS (3) \\
5 & II (1), VIII (6), IX (1) & E & FE (1) \\
6 & VIII (2) & H & CH (1) \\
7 & VIII (4) & D & FJ (1), MB (2), SS (2), VS (1) \\
8 & VIII (2) & D & FJ (3), MB (1) \\
9 & VIII (1), IX (1) & D & FJ (2) \\
& II (1), IV (2), VII (3), VIII (1) & D & CH (4) MB (1) \\
10 & B & FJ (2), SA (1) \\
11 & II (1), IV (2), V (1) & I & CR (4) \\
12 & I (1), II (4), IV (1) & C & CR (4), LS (2) \\
13 & II (1), IV (1) & C & CR (2) \\
14 & I (1), II (1) & C & CR (1), LS (1) \\
15 & I (1), VII (1) & C & PP (1) \\
16 & I (1), IV (1), VII (1) & J & SA (1) \\
& IV (2) & E & FE (1) \\
& & F & FJ (1), MB (1) \\
\hline
\end{tabular}

$\mathrm{CH}$, cheese; $\mathrm{CR}$, cooked rice; FE, fried eggs; FJ, fruit juice; LS, lentil soup; MB, milk beverage; OS, oat soup; PFGE, pulsed-field gel electrophoresis; PM, powdered milk; PP, potato puree; SA, salad; SS, spinach soup; VS, vegetables soup.

(Fig. 1B), the results showed that a specific toxigenic profile could be isolated from various foods or day care centers; this indicates that there is no relationship between these variables, probably because the foods came from raw materials from diverse sources.

\section{Genomic heterogeneity of B. cereus s.I. isolates}

PFGE fingerprinting was successful in separating the B. cereus s.l. isolates and a high heterogeneity was detected. In total, 105 PFGE patterns are shown in the dendrogram that correspond to 101 B. cereus s.l. isolates from foods and four reference strains (Fig. 2). No well-defined PFGE profiles were obtained for 11 isolates, even after several assays, making them untypeable and therefore, were not included in this analysis. Sixty-eight of the 101 isolates grouped into 16 clusters, the other 33 isolates and 4 reference strains clustered separately.

Overall, a large genomic heterogeneity was detected and toxigenic profiles were widely distributed among the strains, with isolates from the same food type or harboring the same toxigenic profile presenting distinct banding patterns. In addition, particular genomic clusters presented different toxigenic profiles (e.g., clusters 1, 3, and 4) (Fig. 2 and Table 2). These findings indicate that the toxigenic profile is not related to the genomic background; in other words, no toxigenic profile was exclusively found on a specific cluster, as previously reported (Chaves et al., 2011; Lee et al., 2012).

Despite the wide genomic diversity, it was observed that clusters 10-13 were related; they included isolates exclusively from day care center $\mathrm{C}$; furthermore, four different toxigenic profiles (I, II, IV, and V) were found in these clusters. Similarly, clusters 3-8 were related, and included $B$. cereus s.l. isolated mostly from day care center D with toxigenic profile VIII predominantly detected. In particular, clusters 5-7 carried highly related isolates, with a unique toxigenic profile; they were also from day care center D and differed in sampling date and food. This result may indicate a cross-contamination by persistent strains originating from the environment, raw materials, or the food-processing machinery in this day care center. Indeed, the analysis of the genomic diversity of isolates makes it possible to find contaminations with particular B. cereus strains in foods, as previously indicated (Samapundo et al., 2011; Mudagza and Buys, 2017).

Conversely, in day care center $\mathrm{C}$, a particular food, for example cooked rice, was contaminated by a mixture of isolates belonging to various genomic groups $(1,10-13$, and 16) and toxigenic profiles (II and IV predominantly) (Fig. 2). A possible explanation for this finding is related to the various steps taking place in the processing chain, in which diverse food contamination sources may be involved, as it was previously shown for pasta (Dierick et al., 2005).

\section{Conclusions}

Our results showed that $B$. cereus s.l. isolates present in ready-to-eat foods and powdered milk in the day care centers represent a potential risk for food poisoning in the children population given that all isolates contained enterotoxin genes. In addition, the high number of pulsotypes found indicates a high genomic heterogeneity among the $B$. cereus 
isolated from the various foods; such heterogeneity may even suggest that species within the $B$. cereus group may be present among the isolates and further studies should be carried out for their characterization and identification. Finally, this study provides useful information on the safety of ready-to-eat foods in day care centers and the results point out to the importance of additional studies to understand the distribution of different toxin genes among B. cereus s.l. isolates, enabling detailed risk assessment.

\section{Acknowledgments}

The authors thank Ann Van De Walle (ILVO, Technology and Food Science Unit, Melle, Belgium) for kindly providing technical support.

\section{Disclosure Statement}

No competing financial interests exist.

\section{Funding Information}

This study was partially supported by the Flanders Research Institute for Agriculture, Fisheries and Food (ILVO), Technology and Food Science Unit, Melle, Belgium. J.S.C. is a beneficiary received financial support for her doctoral studies from Colciencias (grant no. 647).

\section{Supplementary Material}

Supplementary Table S1

\section{References}

Altayar M, Sutherland AD. Bacillus cereus is common in the environment but emetic toxin producing isolates are rare. J Appl Microbiol 2006;100:7-14.

Alvarenga V, Brancini G, Silva E, Da Pia A, Campagnollo F, Braga G, Hubinger M, Sant'Ana A. Survival variability of 12 strains of Bacillus cereus yielded to spray drying of whole milk. Int J Food Microbiol 2018;286:80-89.

Ankolekar C, Rahmati T, Labbe RG. Detection of toxigenic Bacillus cereus and Bacillus thuringiensis spores in U.S. rice. Int J Food Microbiol 2009;128:460-466.

Asano S, Nukumizu Y, Bando H, Iizuka T, Yamamoto T. Cloning of novel enterotoxin genes from Bacillus cereus and Bacillus thuringiensis. Appl Environ Microbiol 1997;63:1054-1057.

Arslan S, Eyi A, Küçüksarı R. Toxigenic genes, spoilage potential, and antimicrobial resistance of Bacillus cereus group strains from ice cream. Anaerobe 2014;25:42-46.

Banykó J, Vyletelová M. Determining the source of Bacillus cereus and Bacillus licheniformis isolated from raw milk, pasteurized milk and yoghurt. Lett Appl Microbiol 2009;48:318-323.

Böhm M, Huptas C, Krey V, Scherer S. Massive horizontal gene transfer, strictly vertical inheritance and ancient duplications differentially shape the evolution of Bacillus cereus enterotoxin operons $h b l, c y t K$ and nhe. BMC Evol Biol 2015;15:246.

Ceuppens S, Boon N, Uyttendaele M. Diversity of Bacillus cereus group strains is reflected in their broad range of pathogenicity and diverse ecological lifestyles. FEMS Microbiol Ecol 2013;84:433-450.

Chaves JQ, Pires ES, Vivoni AM. Genetic diversity, antimicrobial resistance and toxigenic profiles of Bacillus cereus isolated from food in Brazil over three decades. Int $\mathrm{J}$ Food Microbiol 2011;147:12-16.
D’Alessandro B, Antúnez K, Piccini C, Zunino P. DNA extraction and PCR detection of Paenibacillus larvae spores from naturally contaminated honey and bees using sporedecoating and freeze-thawing techniques. World J Microbiol Biotechnol 2007;23:593-597.

De Jonghe V, Coorevits A, Vandroemme J, Heyrman J, Herman L, De Vos P, Heyndrickx M. Intraspecific genotypic diversity of Bacillus species from raw milk. Int Dairy J 2008;18:496505.

Dierick K, Van Coillie E, Święcicka I, Meyfroidt G, Devlieger H, Meulemans A, Hoedemaekers G, Fourie L, Heyndrickx M, Mahillon J. Fatal family outbreak of Bacillus cereus-associated food poisoning. J Clin Microbiol 2005;43:4277-4279.

Dréan P, McAuley C, Moore S, Fegan N, Fox E. Characterization of the spore-forming Bacillus cereus sensu lato group and Clostridium perfringens bacteria isolated from the Australian dairy farm environment. BMC Microbiol 2015;15:38.

Ehling-Schulz M, Vukov N, Schulz A, Shaheen R, Andersson M, Märtlbauer E, Scherer S. Identification and partial characterization of the nonribosomal peptide synthetase gene responsible for cereulide production in emetic Bacillus cereus. Appl Environ Microbiol 2005;71:105-113.

Fogele B, Granta R, Valcin O, Berzins A. Occurrence and diversity of Bacillus cereus and moulds in spices and herbs. Food Control 2018;83:69-74.

Forero A, Galindo M, Morales G. Aislamiento de Bacillus cereus en restaurantes escolares de Colombia. Biomédica 2018; 38:338-344.

Frentzel H, Kraushaar B, Krause G, Bodi D, WichmannSchauer H, Appel B, Mader A. Phylogenetic and toxinogenic characteristics of Bacillus cereus group members isolated from spices and herbs. Food Control 2018;83:90-98.

Fricker M, Reissbrodt R, Ehling-Schulz M. Evaluation of standard and new chromogenic selective plating media for isolation and identification of Bacillus cereus. Int $\mathrm{J}$ Food Microbiol 2008;121:27-34.

Gdoura-Ben Amor M, Siala M, Zayani M, Grosset N, Smaoui S, Messadi-Akrout F, Baron F, Jan S, Gautier M, Gdoura R. Isolation, identification, prevalence, and genetic diversity of Bacillus cereus group bacteria from different foodstuffs in Tunisia. Front Microbiol 2018;9:447.

Gholamiandekhordi AR, Ducatelle R, Heyndrickx M, Haesebrouck F, Van Immerseel F. Molecular and phenotypical characterization of Clostridium perfringens isolates from poultry flocks with different disease status. Vet Microbiol 2006; 113:143-152.

Granum PE, O'Sullivan K, Lund T. The sequence of the nonhaemolytic enterotoxin operon from Bacillus cereus. FEMS Microbiol Lett 1999;177:225-229.

Guinebretière MH, Broussolle V, Nguyen-The C. Enterotoxigenic profiles of food-poisoning and food-borne Bacillus cereus strains. J Clin Microbiol 2002;40:3053-3056.

Guirdham O. Child Care Market by Type (Baby and Child Day Care Centers, Pre Kindergarten and Preschool Centers, Nursery Schools, and Overall Child Care), Market Overview and Market Players-Global Forecast to 2022. 2019. Available at: https:// www.thebusinessresearchcompany.com/report/child-care-market, accessed August 5, 2019.

INS. Informe de la Vigilancia de las Enfermedades Transmitidas por Alimentos. Grupo Funcional ETA-SVCSP. Colombia: Instituto Nacional de Salud, Ministerio de la Protección Social, 2007, p. 9.

INS. Perfil de Riesgo Bacillus cereus en Alimentos Listos Para el Consumo no Industrializados. Unidad de Evaluación de 
Riesgos Para la Inocuidad de los Alimentos, ed. Colombia: Instituto Nacional de Salud, Ministerio de la Protección Social, 2011.

ISO. ISO 7932:2004. Microbiology of Food and Animal Feeding Stuffs-Horizontal Method for the Enumeration of Presumptive Bacillus cereus-Colony-Count Technique at 30 Degrees $C$. Geneva, Switzerland: International Organization for Standardization, 2004.

Jiménez G, Urdiain M, Cifuentes A, Lopez-Lopez AR, Blanch A, Tamames J, Kämpfer P, Kolstø AB, Ramón D, Martínez JF, Codoñer FM, Rosselló-Móra R. Description of Bacillus toyonensis sp. Nov., a novel species of Bacillus cereus group, and pairwise genome comparisons of the species of the group by means of ANI calculations. Syst Appl Microbiol 2013;36: 383-391.

Kim B, Bang J, Kim H, Kim Y, Kim B, Beuchat LR, Ryu, JH. Bacillus cereus and Bacillus thuringiensis spores in Korean rice: Prevalence and toxin production as affected by production area and degree of milling. Food Microbiol 2014;42: 89-94.

Kumari S, Sarkar PK. Prevalence and characterization of $\mathrm{Ba}$ cillus cereus group from various marketed dairy products in India. Dairy Sci Technol 2014;94:483-497.

Lee N, Kim M, Chang H, Choi S, Chun H. Genetic diversity, antimicrobial resistance, toxin gene profiles, and toxin production ability of Bacillus cereus isolates from doenjang, a Korean fermented soybean paste. J Food Saf 2017;37:12363.

Lee N, Sun JM, Kwon KY, Kim HJ, Koo M, Chun HS. Genetic diversity, antimicrobial resistance, and toxigenic profiles of Bacillus cereus strains isolated from Sunsik. J Food Prot 2012;75:225-230.

Lin Y, Ren F, Zhao L, Guo H. Genotypes and the persistence survival phenotypes of Bacillus cereus isolated from UHT milk processing lines. Food Control 2017;82:48-56.

Liu Y, Du J, Lai Q, Zeng R, Ye D, Xu J, Shao Z. Proposal of nine novel species of the Bacillus cereus group. Int J Syst Evol Microbiol 2017;67:2499-2508.

Logan NA. Bacillus and relatives in foodborne illness. J Appl Microbiol 2012;112:417-429.

López AC, Alippi AM. Enterotoxigenic gene profiles of $\mathrm{Ba}$ cillus cereus and Bacillus megaterium isolates recovered from honey. Rev Argent Microbiol 2010;42:216-225.

López AC, Minnaard J, Pérez PF, Alippi AM. A case of intoxication due to a highly cytotoxic Bacillus cereus strain isolated from cooked chicken. Food Microbiol 2015;46:195-199.

Lund T, De Buyser ML, Granum PE. A new cytotoxin from Bacillus cereus that may cause necrotic enteritis. Mol Microbiol 2000;38:254-261.

Miller R, Beno S, Kent D, Carroll L, Martin N, Boor K, Kovac J. Bacillus wiedmannii sp. nov., a psychrotolerant and cytotoxic Bacillus cereus group species isolated from dairy foods and dairy environments. Int J Syst Evol Microbiol 2016;66: 4744-4753.

Moravek M, Wegscheider M, Schulz A, Dietrich R, Bürk C, Märtlbauer E. Colony immunoblot assay for the detection of haemolysin BL enterotoxin producing Bacillus cereus. FEMS Microbiol Lett 2004;238:107-113.

Mudagza DT, Buys EM. Diversity of Bacillus cereus strains in extended shelf life. Int Dairy J 2017;73:144-150.
Ngamwongsatit P, Buasri,W, Pianariyanon P, Pulsrikarn C, Ohba M, Assavanig A, Panbangred W. Broad distribution of enterotoxin genes ( $h b l C D A$, nheABC, cytK, and entFM) among Bacillus thuringiensis and Bacillus cereus as shown by novel primers. Int J Food Microbiol 2008;121:352-356.

$\emptyset \mathrm{kstad}$ O, Kolst $\varnothing$ A. Genomics of Bacillus species, In: Genomics of Foodborne Bacterial Pathogens. Wiedmann M, Zhang W, eds. New York: Springer, 2011, pp. 29-53.

Papan C, Förster K, Herterich R, Schulze A, Schubert S, Flemmer A. Identification and containment of a cluster of two Bacillus cereus infections in a neonatal intensive care unit. Can J Infect Dis Med Microbiol 2019;2019:1506583.

Park K, Kim H, Jeong M, Koo M. Occurrence of toxigenic Bacillus cereus and Bacillus thuringiensis in Doenjang, a Korean fermented soybean paste. J Food Prot 2016;79:605612.

Ramarao N, Sanchis V. The pore-forming haemolysins of $\mathrm{Ba}$ cillus cereus: A review. Toxins 2013;5:1119-1139.

Saleh-Lakha S, Leon-Velarde C, Chen S, Lee S, Shannon K, Fabri M, Downing G, Keown B. A study to assess the numbers and prevalence of Bacillus cereus and its toxins in pasteurized fluid milk. J Food Prot 2017;80:1085-1089.

Samapundo S, Heyndrickx M, Xhaferi R, Devlieghere F. Incidence, diversity and toxin gene characteristics of Bacillus cereus group strains isolated from food products marketed in Belgium. Int J Food Microbiol 2011;150:34-41.

Sánchez J, Correa M, Aceves A, Castañeda L. Direct detection of toxigenic Bacillus cereus in dietary complement for children and cassava starch. Rev Colomb Quim 2014;43:5-9.

Silva, M., Fujimoto, G., Schneid, I., Kabuki, D., Kuaye, A. Enterotoxigenic profile, antimicrobial susceptibility, and biofilm formation of Bacillus cereus isolated from ricotta processing. Int Dairy J 2014;38:16-23.

Stackebrandt E, Liesack W. The potential of rDNA in identification and diagnostics. In: Kessler C, ed. Nonradioactive Labeling and Detection of Biomolecules. Berlin: Springer, 1992, pp. 232-239.

Stenfors LP, Fagerlund A, Granum PE. From soil to gut: $B a-$ cillus cereus and its food poisoning toxins. FEMS Microbiol Rev 2008;32:579-606.

Yang IC, Shih DY, Huang TP, Huan YP, Wang JY, Pan TM. Establishment of a novel multiplex PCR assay and detection of toxigenic strains of the species in the Bacillus cereus group. J Food Prot 2005;68:2123-2130.

Yang Y, Gu H, Yu X, Zhan L, Chen J, Luo Y, Zhang Y, Zhang Y, Lu Y, Jiang J, Mei L. Genotypic heterogeneity of emetic toxin producing Bacillus cereus isolates from China. FEMS Microbiol Lett 2017;364:fnw237.

Address correspondence to:

Laura M. Castañeda-Sandoval, PhD

Grupo BioMicro

Escuela de Microbiología

Universidad de Antioquia

Calle 70 no. 52-21

Medellín 1226

Colombia

E-mail: laura.castaneda@udea.edu.co 